\title{
Studi Pola Sebaran Buangan panas PT. Pertamina Up V Balikpapan Di Perairan Kampung Baru, Teluk Balikpapan
}

\author{
Rizkiyah, Denny Nugroho S, Purwanto \\ Program Studi Oseanografi, Fakultas Perikanan dan Ilmu Kelautan, Universitas Diponegoro \\ Kampus Tembalang, Semarang 50275 Telp/Fax. 024-7474698 \\ Email : rizkikiyah@gmail.com
}

\begin{abstract}
Abstrak
Teluk Balikpapan merupakan wilayah industri di Kalimantan, salah satunya terdapat industri pengolahan minyak dan gas bumi PT Pertamina UP V. Aktivitas pengolahan minyak dan gas bumi menghasilkan buangan sisa industri, salah satunya adalah buangan panas. Penelitian ini bertujuan untuk mengetahui pola sebaran buangan panas yang bersumber dari buangan PT. Pertamina UP V Balikpapan yang dipengaruhi oleh pola pergerakan arus. Data yang digunakan dalam penelitian ini berupa data arus, pasang surut, peta batimetri, teperatur perairan, data temperatur dan debit buangan panas. Lokasi penelitian dilakukan di sekitar Perairan Kampung Baru, Teluk Balikpapan . Studi pola sebaran buangan panas dikaji dengan menggunakan pendekatan model hidrodinamika. Hasil simulasi model menunjukan bahwa kecepatan arus di Perairan Teluk Balipapan sebesar 0,01 $\mathrm{m} / \mathrm{det}-0,53 \mathrm{~m} /$ det dengan arah arus dominan selatan dan utara. Jarak terjauh sebaran panas terjadi saat kondisi purnama periode pasang tertinggi yaitu bergerak sejauh $1,44 \mathrm{~km}$ ke arah selatan dari titik outlet dengan temperatur buangan sebesar $36^{\circ} \mathrm{C}$ hingga temperatur normal perairan sebesar $29^{\circ} \mathrm{C}$.
\end{abstract}

Kata Kunci : Sebaran buangan panas, arus, temperatur perairan, Teluk Balikpapan.

\begin{abstract}
Balikpapan Bay is an industrial area in Borneo, one of the industries existed there is oil and gas processing plants of PT.Pertamina UP V. The processing activity of oil and gas produce some waste, one of them is waste heat. The aim of this study is to determine the distribution pattern of waste heat derived from the effluent of PT.Pertamina UP V Balikpapan that influenced by the current movement patterns. The data used in this study are in the form of sea currents, tides data, bathymetric maps, water temperature, and temperature \& debit flow of waste heat. The location of the research conducted in waters around Kampung Baru, Balikpapan Bay. The hydrodynamic model is used to examine the pattern of distribution of waste heat. The results of the simulation models show that the current velocity in the Balikpapan Bay is $0.01 \mathrm{~m} / \mathrm{s}-0.53$ $\mathrm{m} / \mathrm{s}$ with the dominant current direction to the south and the north, the distribution of waste heat is moving according to the pattern of water flow which moves to the south and the north. The farthest distance distribution of heat occurs in the condition of the highest tide, it moves as far as $1.54 \mathrm{~km}$ to the south of the point of discharge outlet with a temperature of $36^{\circ} \mathrm{c}$ to $29^{\circ} \mathrm{c}$ at ambient water temperature.
\end{abstract}

Keywords: Distribution of waste heat, currents, water temperature, Balikpapan Bay.

\section{PENDAHULUAN}

Teluk Balikpapan merupakan salah satu wilayah industri pengolahan terutama minyak dan gas bumi di daerah Kalimantan, yang salah satunya terdapat PT. Pertamina (Persero) Refinery Unit V Balikpapan(Tahir dan Susilo, 2002). Aktivitas industri ini menghasilkan limbah yang tidak sedikit yang berupa limbah cair maupun non cair, contohnya berupa buangan air yang bertemperatur cukup tinggi atau buangan panas ke laut. Luasan nilai sebaran buangan panas dipengaruhi faktorfaktor volume limbah, temperatur air limbah, temperatur ambien air laut dan juga pergerakan air laut dimana faktor terbesarnya yaitu arus pasang surut (Cahyana,2011). Tujuan dari penelitian ini adalah untuk mengetahui pola sebaran panas dari buangan limbah panas PT. Pertamina (Persero)
*) Corresponding author

buloma.undip@gmail.com http://ejournal.undip.ac.id/index.php/buloma

Diterima/Received : 15-02-2016

Disetujui/Accepted : 25-03-2016 
Refinery Unit V Balikpapan di Perairan Teluk Balikpapan menggunakan pendekatan hidrodinamika. Hasil penelitian ini diharapkan dapat memberikan informasi pola sebaran panas di
Perairan Teluk Balikpapan serta dapat digunakan dalam analisis dampak lingkungan untuk wilayah sekitar Teluk Balikpapan.

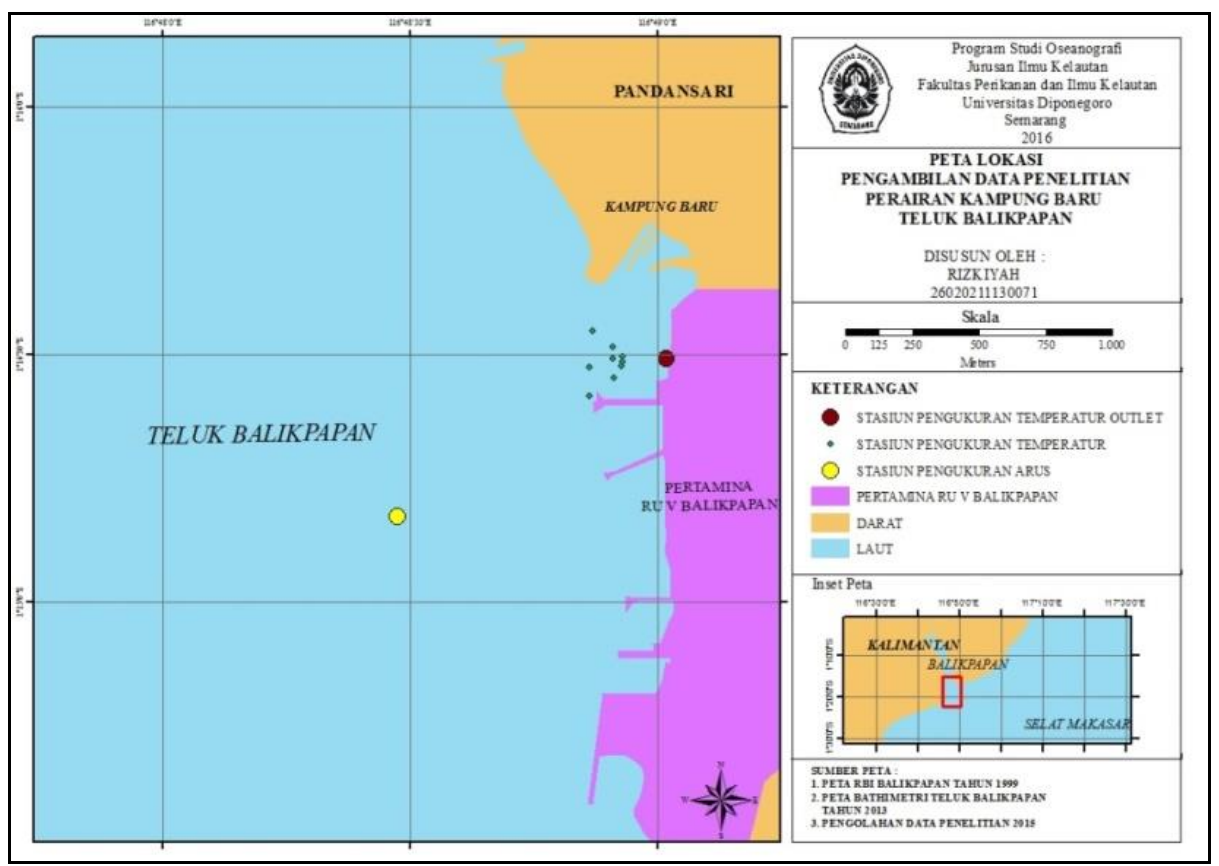

Gambar 1. Lokasi Penelitian

\section{MATERI DAN METODE}

Materi penelitian yang digunakan berupa data primer dan data sekunder. Berdasarkan jenis dan fungsinya, data primer yang digunakan meliputi data temperatur, pasang surut, arah dan kecepatan arus yang telah ditentukan jumlah dan titik stasiunnya dan data sekunder yang digunakan yaitu berupa peta batimetri dan data angin. Pada penelitian ini digunakan metode kuantitatif. Menurut Sugiyono (2008), metode kuantitatif merupakan metode penelitian yang digunakan untuk meneliti pada popolasi atau suatu sampel, pengumpulan data menggunakan instrumen penelitian, analisa data bersifat kuantitatif atau statistik dengan tujuan menguji hipotesis yang telah ditetapkan. Hasil penelitian di harapakan dapat memberi gambaran yang beskala tentang persebaran panas di Perairan Teluk Balikpapan pada waktu yang terbatas dan tempat tertentu, berupa gambaran yang memiliki nilai-nilai besaran berdasarkan data-data kuantitatif. Pengambilan data dilakukan pada tanggal $16-30$ April 2015, disekitar titik pembuangan sisa industri di Perairan Kampung Baru, Teluk Balikpapan.

Pengolahan data pasang surut menggunakan metode Admiralty yang diolah dengan menggunakan software MS.Excel, untuk mengetahui nilai Formzahl yang dapat mengklasifikasikan jenis pasut perairan tersebut. Data arus yang diperoleh dari pengukuran lapangan diolah dengan menggunakan perangkat Ms Excel, yang akan menghasilkan nilai arah dan kecepatan arus dalam vektor U dan V. Pengolahan data arus ini disajikan dan digunakan sebagai data verifikasi hasil model modul hidrodinamika yang juga berupa arah vektor kecepatan U dan V. Data arus juga diolah menjadi 5 pengolahan data arus yaitu : current rose menggunakan software wr.plot, stickplot dan grafik perbandingan elevasi dengan kecepatan dan arah arus. Pengolahan arus menggunakan software World Current, untuk mendapatkan grafik scater plot dan juga grafik pemisah yang menunjukan arus lapangan, arus astronomic dan juga arus residual.

Arah dan kecepatan arus menggunakan pemodelan hidrodinarnika dan persebaran buangan panas yang dikaji berdasarkan temperaturnya juga diolah dengan pemodelan menggunakan software MIKE 21. Verifikasi hasil model dilakukan untuk mengetahui kesesuaian model yang telah dibuat dengan data arus hasil pengukuran lapangan. Data yang di verifikasi berupa data arus dan juga pasang surut. 


\section{HASIL DAN PEMBAHASAN \\ Pasang Surut}

Hasil analisis elevasi muka air (Gambar 2), tipe pasang surut Perairan Teluk Balikpapan adalah pasang surut campuran condong ke harian ganda (Mixed Tide Prevailling Semidiurnal) dengan nilai formzahl $0,26(0,25<f \leq 1,25)$. Hal ini sesuai dengan pernyataan Triatmodjo (1999) dimana pasang surut ini terjadi dua kali pasang dan surut dalam satu hari, namun berbeda dalam tinggi dan periodenya. Pasang surut jenis ini terdapat di Indonesia bagian timur termasuk Teluk Balikpapan.

Gambar 2 menghasilkan elevasi rerata (mean sea level) 138,47 cm, elevasi tinggi (high water level) $280 \mathrm{~cm}$, elevasi tertinggi (highest high water level) $321,95 \mathrm{~cm}$, elevasi rendah (low water level) $20 \mathrm{~cm}$, elevasi terendah (lowest low water level) $-42,47 \mathrm{~cm}$.

\section{Arus}

Pengolahan data kecepatan arus dan arah arus yang diperoleh dari pengukuran lapangan menghasilkan nilai komponen arus dalam arah $\mathrm{U}$ dan V. Kecepatan arus total pada titik pengukuran arus lapangan memiliki nilai yang berkisar antara
$0,03 \mathrm{~m} /$ det - $0,11 \mathrm{~m} /$ det. Untuk kecepatan komponen arus $\mathrm{U}$ dan $\mathrm{V}$ nilai maksimum kecepatan yaitu sebesar $0,032 \mathrm{~m} /$ det dan 0,10 $\mathrm{m} /$ det. Pengolahan data arus yang menghasilkan Scatterplot menunjukan arah arus cenderung bergerak bolak balik dominan kearah utara dan selatan berkisar antara $\pm 354^{\circ}$ dan $\pm 174^{\circ}$ (gambar 4).Pengolahan data arus yang menghasilkan grafik pemisah arus menunjukan bahwa arus pada daerah penelitian ini cenderung arus pasang surut (Gambar 6). Grafik data pengukuran lapangan memiliki bentuk yang sama dengan grafik astronomic, hal ini menunjukan bahwa arus di Perairan Teluk Balikpapan mempunyai jenis arus pasang surut dengan tipe bolak balik.Hal ini sesuai dengan pernyataan Hadi dan Radjawane (2009) bahwa, Arus pasut tipe bolak balik biasanya terdapat pada perairan teluk atau estuari. Arus pasut tipe ini terjadi disaat muka air laut di laut lepas lebih tinggi dari pada di teluk maka, arus pasut bergerak memasuki teluk, keadaan ini disebut flood. Sedangkan pada saat muka air laut di laut lepas lebih rendah dari pada di teluk maka, arus pasut bergerak keluar dari teluk menuju laut lepas, kondisi ini disebut ebb. Arus ini diakibatkan oleh pasang surut.

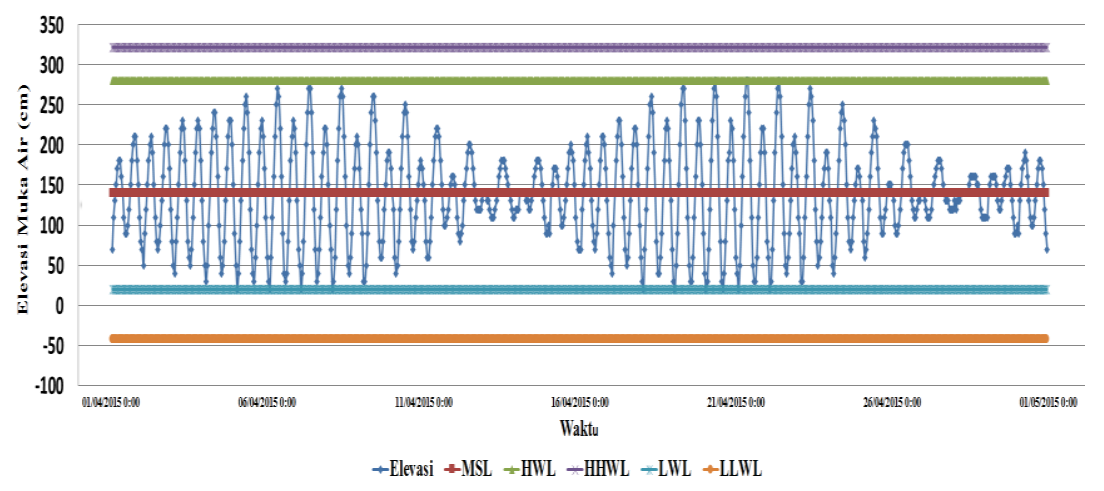

Gambar 2. Fluktuasi pasang surut muka air Teluk Balikpapan, Kalimantan Timur bulan April 2015

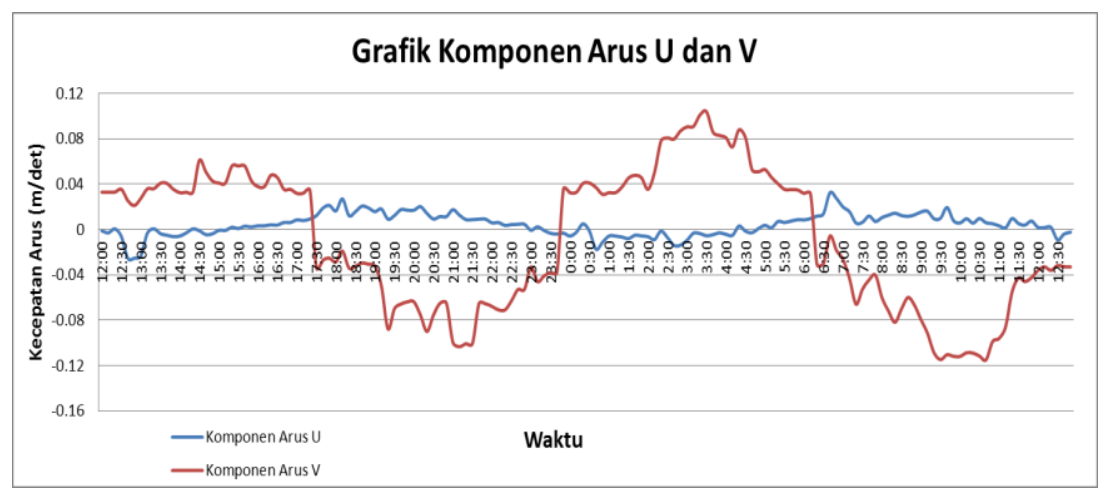

Gambar 3. Nilai komponen arus di Perairan Kampung Baru, Teluk Balikpapan 


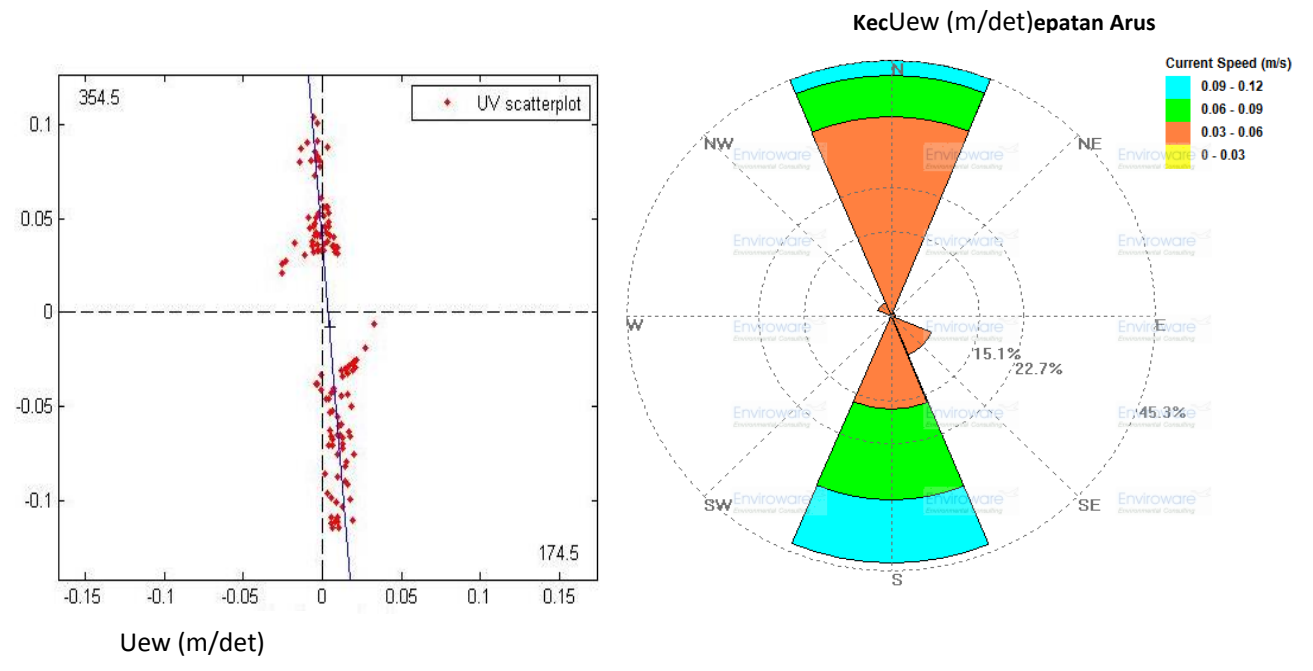

Gambar 4. Scatterplot komponen arus U V dan Currentrose nilai arus pengukuran lapangan

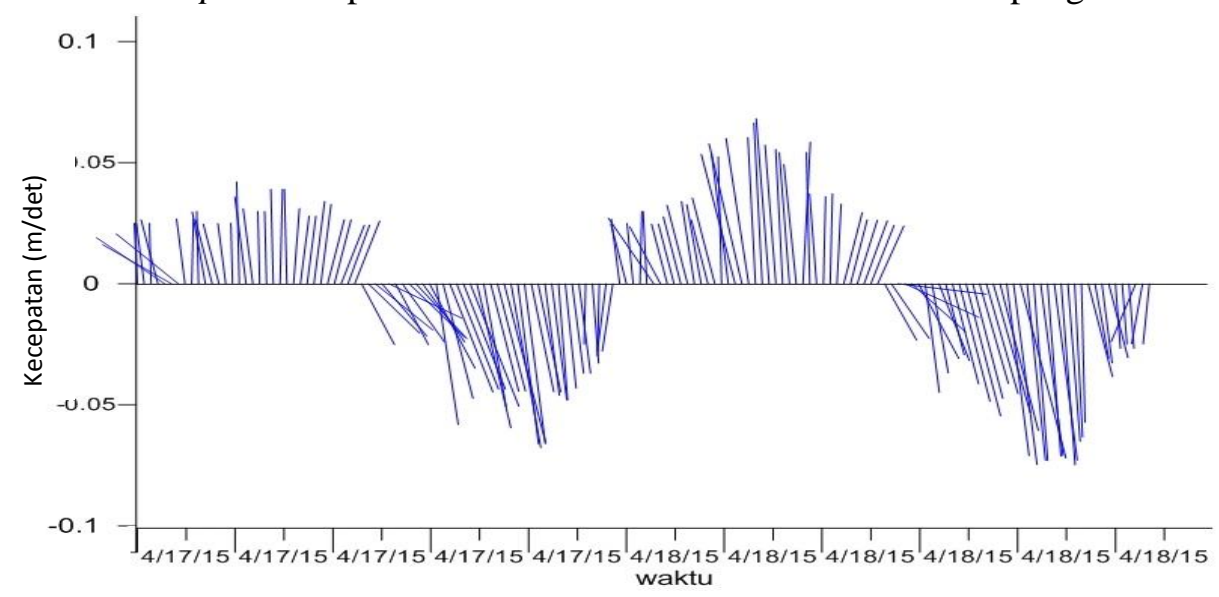

Gambar 5. Stickplot nilai arus pengukuran lapangan

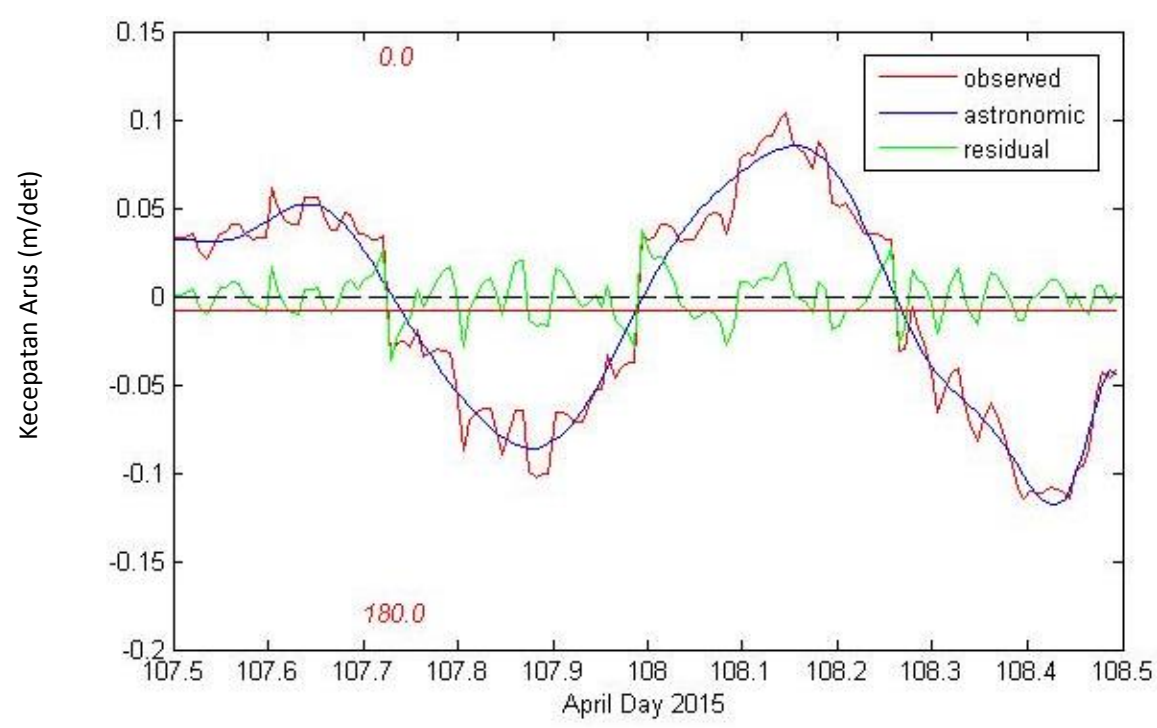

Gambar 6. Grafik pemisah arus 


\section{Hasil Uji Model Pasang Surut}

Berdasarkan hasil perhitungan verifikasi pasang surut hasil pengelolaan data dari Dishidros dengan pasang surut hasil model untuk MRE didapatkan nilai error sebesar $25,23 \%$.

\section{Hasil Uji Model Arus}

Hasil dari perhitungan verifikasi nilai arus total data lapangan dengan nilai arus data hasil model, didapatkan nilai MRE pada daerah pengamatan sebesar $22.74 \%$ dan untuk hasil verifikasi komponen arus $\mathrm{U}$ dan $\mathrm{V}$ data model dengan data hasil pengolahan data lapangan diperoleh untuk komponen $\mathrm{U}$ sebesar 36,87\% dan untuk komponen V sebesar 28,24\%.

\section{Simulasi Model Arus}

Berdasarkan hasil simulasi di Perairan Kampung Baru Teluk Balikpapan besar kecepatan arus dan arah arus saat menuju pasang dan saat menuju surut dapat dilihat pada Gambar 12 dan Gambar 13. Nilai arus di Perairan Teluk Balikpapan berkisar antara $0,01 \mathrm{~m} / \mathrm{det}-0,53$ $\mathrm{m} /$ det dengan arah arus dominan ke selatan dan ke utara.

Kecepatan arus terbesar terjadi saat purnama periode pasang menuju surut dengan kecepatan maksimum sebesar $0,53 \mathrm{~m} /$ det, dengan arah arus ke selatan menuju keluar teluk. Sesuai dengan pernyataan Poerbondono dan Djunasjah (2005) bahwa, kecepatan arus pasut maksimum terjadi pada saat-saat antara pasang dan surut.

\section{Hasil Model Persebaran Buangan Panas}

Hasil model sebaran buangan limbah panas yang berasal dari buangan limbah PT pertamina RU V Balikpapan memiliki debit buangan limbah panas sebesar $\pm 9.032 .400 \mathrm{~m}^{3} /$ bulan yang memiliki temperatur buangan sebesar $36^{\circ} \mathrm{C}$, dan temperatur perairan rerata sebesar $29^{\circ} \mathrm{C}$ dengan skenario model untuk debit buangan limbah sebesar 3,48 $\mathrm{m}^{3} /$ det yang bertemperatur sebesar $36^{\circ} \mathrm{C}$, dibuang secara terus menerus. Hasil model sebaran buangan panas dibagi menjadi dua kondisi berdasarkan pasang surut, yaitu kondisi saat purnama (spring) dan kondisi saat perbani (neap), dimana pada setiap kondisi ini masing - masing di bagi lagi menjadi 4 kondisi berdasarkan periode pergerakan pasang surutnya.

Hasil sebaran temperatur buangan panas dengan waktu permodelan selama 17 hari yang mewakili kondisi purnama dan perbani dimulai dari tanggal 14 - 30 April 2015 dengan interval setiap 10 menit, dapat diketahui bahwa sebaran panas menyebar ke arah utara dan selatan dari sumber buangan dan bergerak searah dengan pergerakan arus yang dihasilkan dari model hidrodinamika. Berdasarkan hasil pembuatan simulasi model sebaran panas dan dikaji dengan menggunakan crossbar, diketahui jarak sebaran panas terjauh yaitu pada kondisi purnama periode pasang tertinggi (selama waktu pemodelan yang ditentukan) dengan jarak 1,44 $\mathrm{km}$ bergerak kearah utara, hal ini dapat dilihat pada Gambar 15, sedangkan jarak sebaran panas terpendek yaitu disaat kondisi perbani periode pasang menuju surut (selama waktu pemodelan yang ditentukan) dengan jarak $656 \mathrm{~m}$ yang bergerak ke arah selatan, pada Gambar 20.

Saat arus bergerak ke arah utara sebaran air bertemperatur tinggi menyebar terjauh ke arah utara, dan disaat arus bergerak kearah selatan sebaran air bertemperatur tinggi akan menyebar terjauh ke arah selatan. Hal ini sesuai dengan pendapat Kennish (2001) dalam Cahaya (2011) yang menyatakan bahwa sebaran air panas kanal pendingin pada air laut sangat dipengaruhi oleh pola kecepatan aliran atau arus laut. Namun persebaran panas ini pada beberapa kondisi, buangan air bertemperatur tinggi ini juga menyebar ke arah yang berlawanan dengan arus namun tidak terlalu jauh. Hal ini dikarenakan selain adanya proses adveksi namun ada juga proses difusi dalam transport temperatur dalam badan air, dimana temperatur buangan yang lebih tinggi menyebar ke temperatur perairan yang lebih rendah. Disamping itu juga dipengaruhi oleh adanya pengaruh dari bangunan pantai yang berada tepat sebelah selatan titik outlet sehingga panas yang ditransfer ke arah selatan sebagian terhalang oleh bangunan pantai, oleh karena itu sebaran buangan air bertemperatur tinggi yang bergerak ke arah selatan memiliki temperatur yang relatif lebih rendah dibandingkan temperatur yang ditransfer kearah utara. 


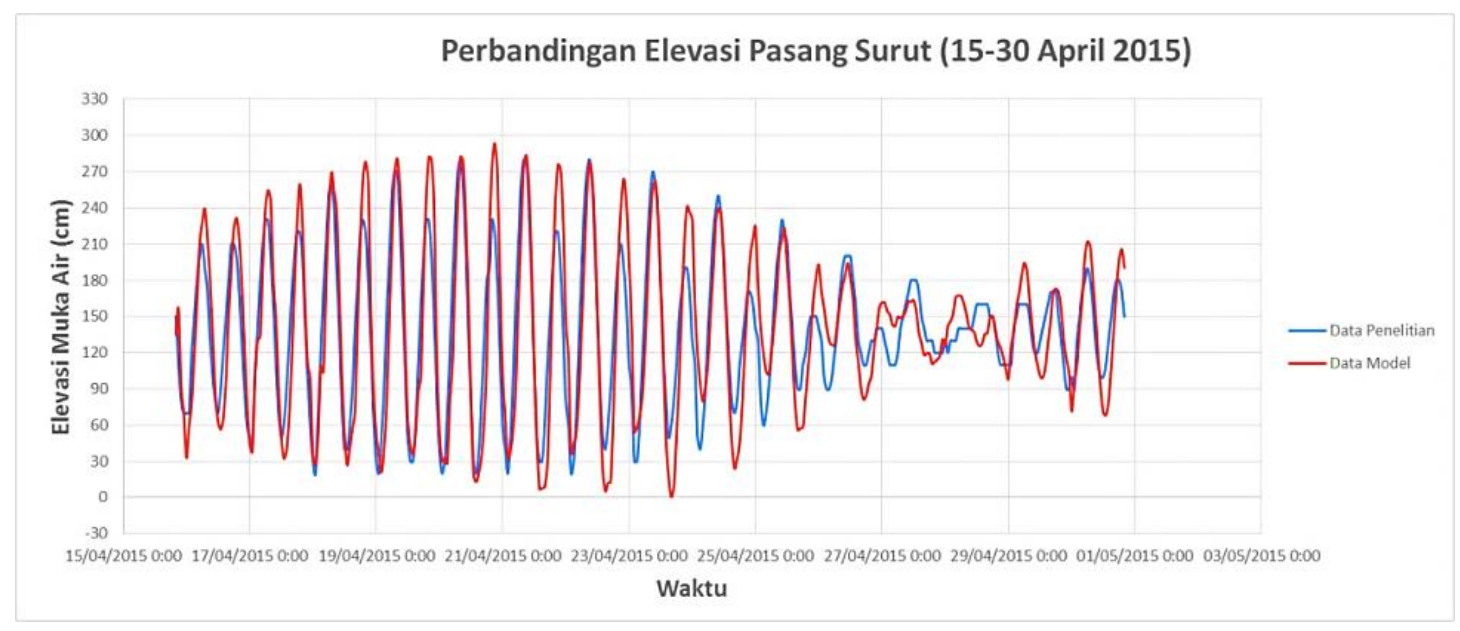

Gambar 7. Perbandingan elevasi pasang surut hasil pengolahan data penelitian dengan model (Sumber: Pengolahan data Dishidros dan hasil model, 2015).

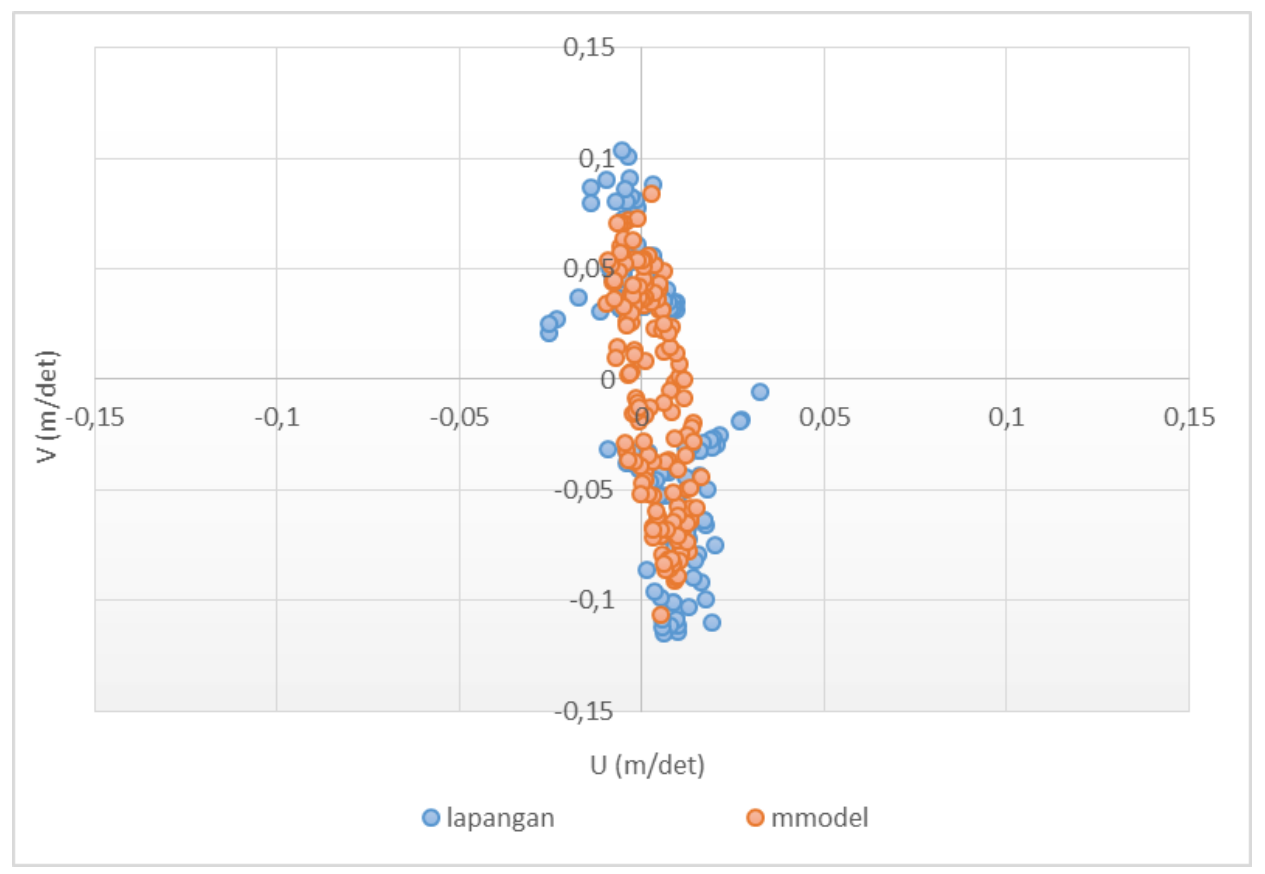

Gambar 8. Verifikasi arus u dan v lapangan dengan model menggunakan scatterplot 


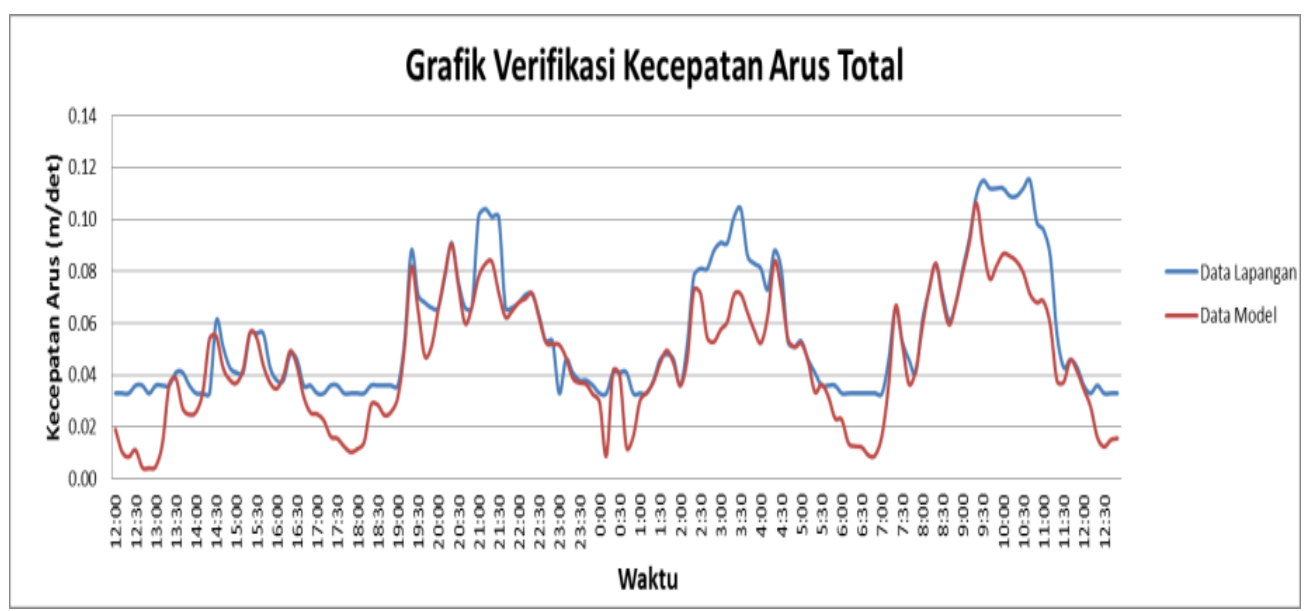

Gambar 9. Grafik verifikasi arus total pengukuran lapangan dengan model

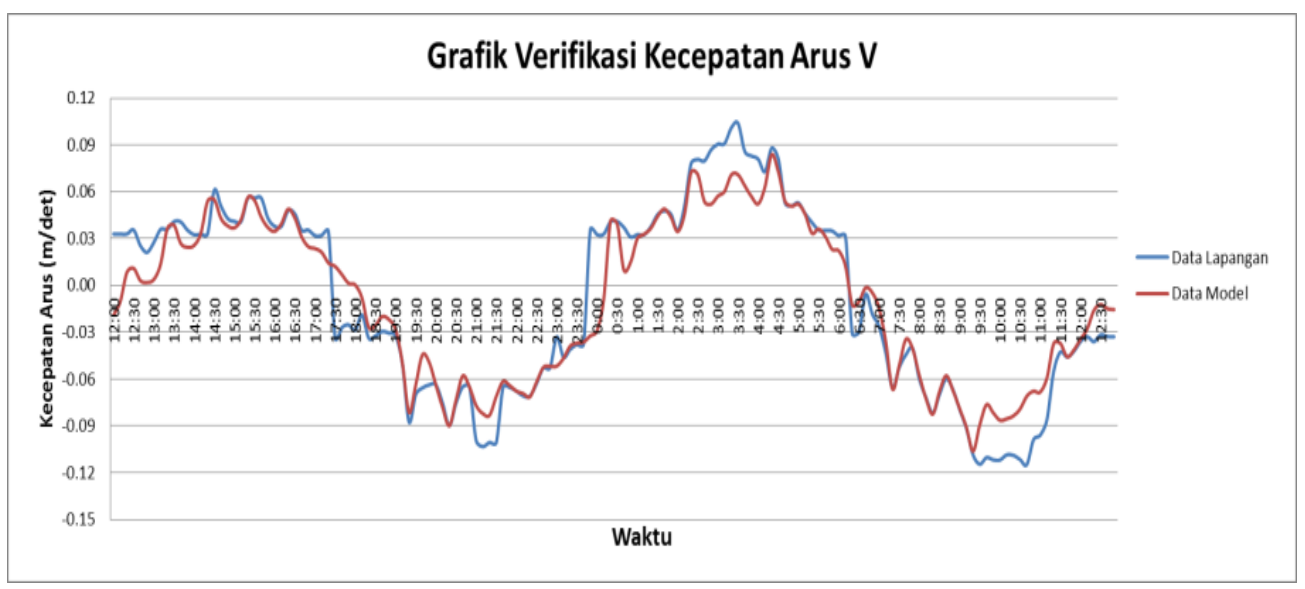

Gambar 10. Grafik verifikasi komponen V pengolahan data pengukuran lapangan dengan model

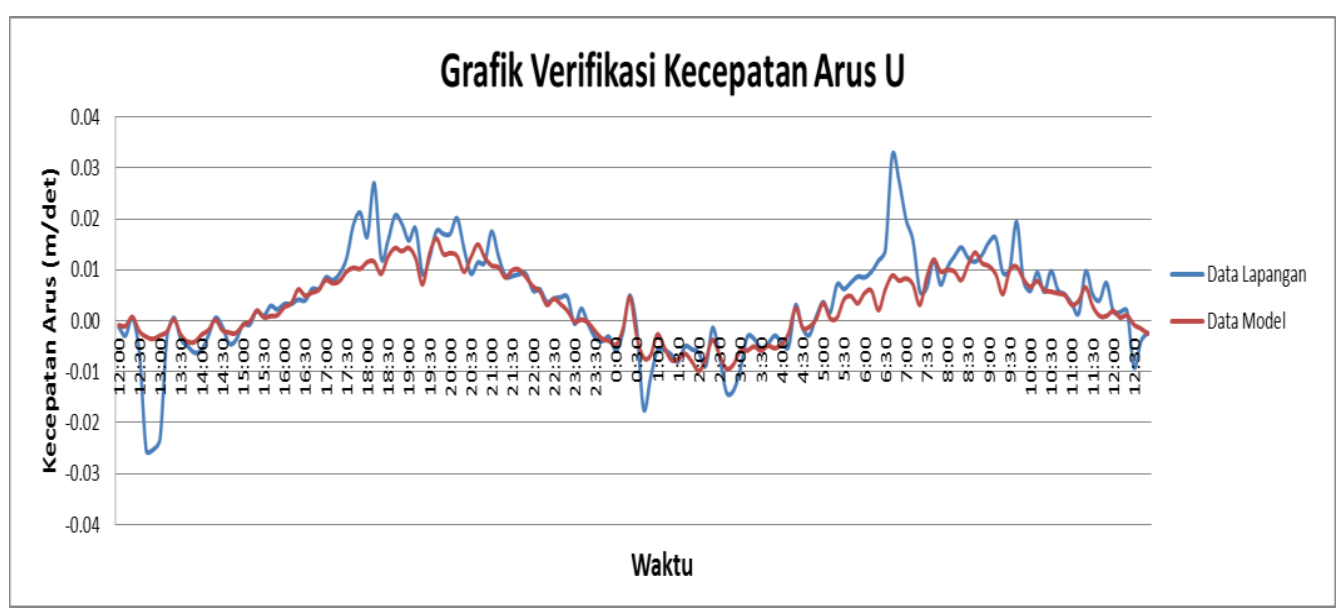

Gambar 11. Grafik verifikasi komponen U pengolahan data pengukuran lapangan dengan model 


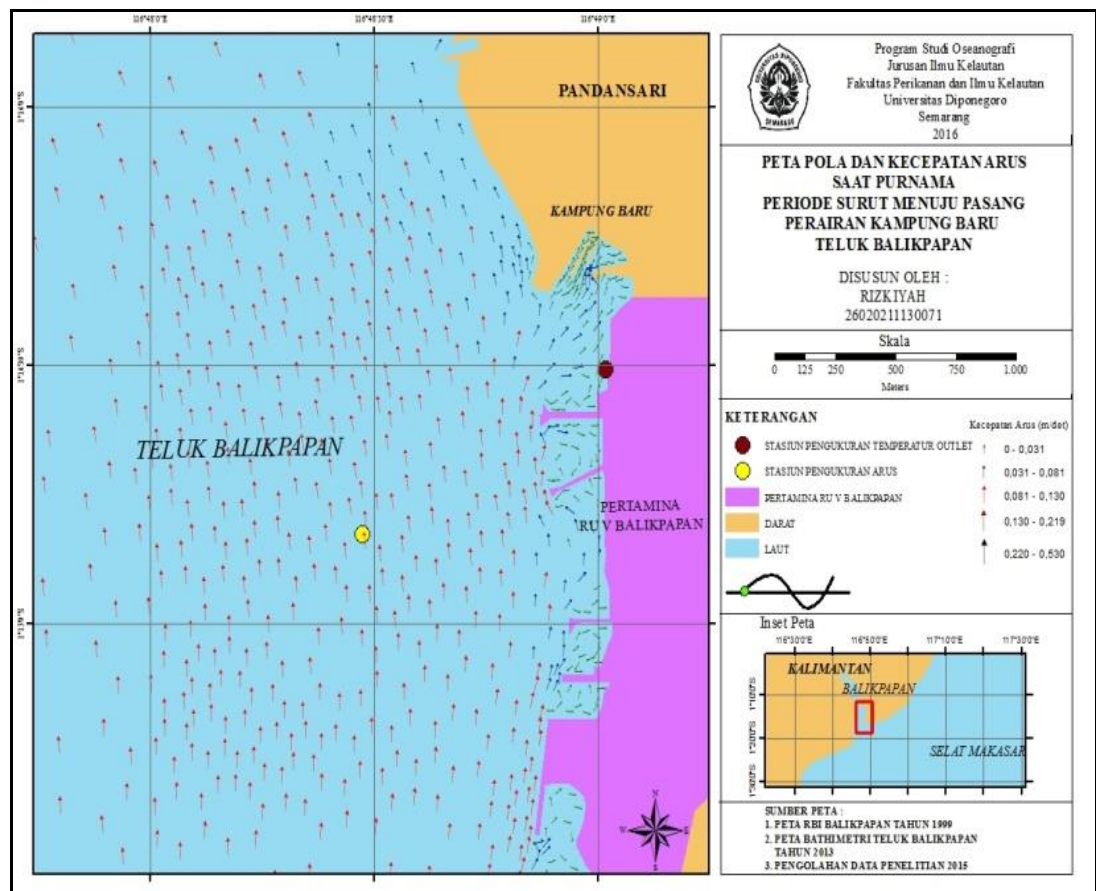

Gambar 12. Pola arus Perairan Kampung Baru, Teluk Balikpapan pada saat purnama periode surut menuju pasang

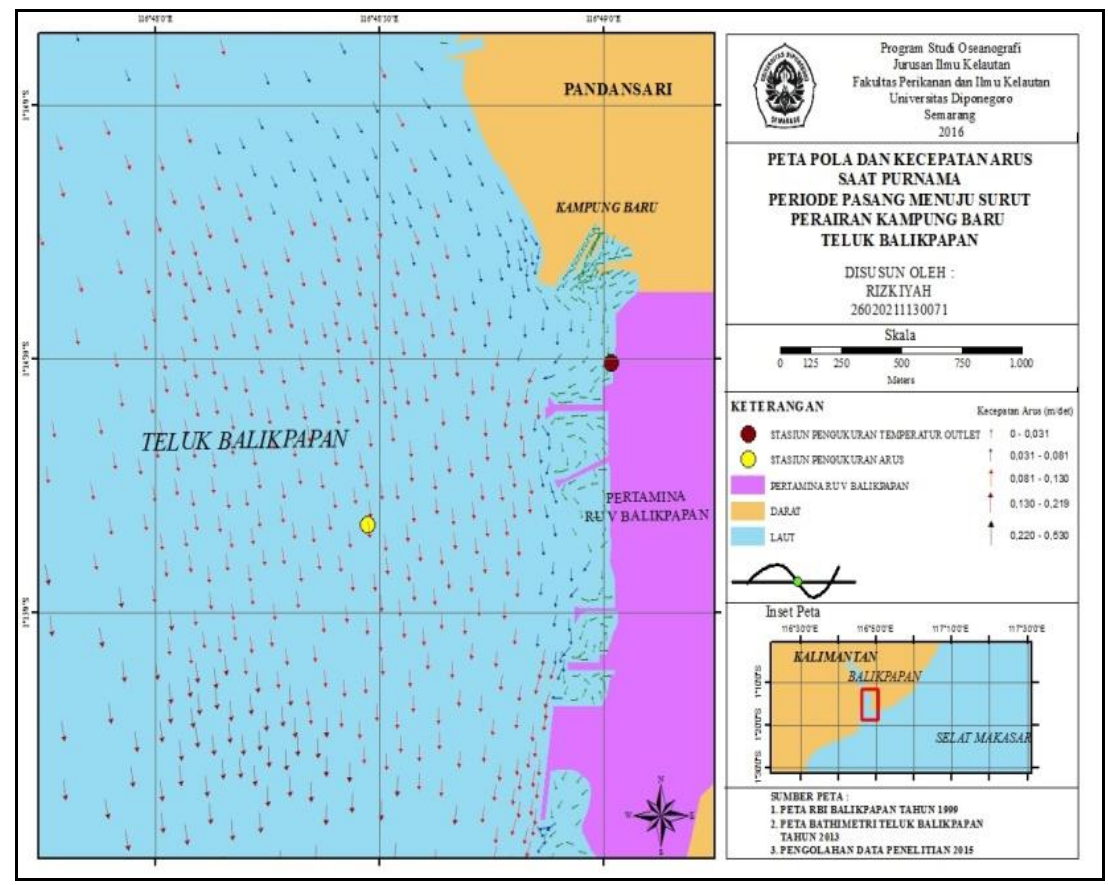

Gambar 13. Pola arus Perairan Kampung Baru, Teluk Balikpapan pada saat purnama periode pasang menuju surut 


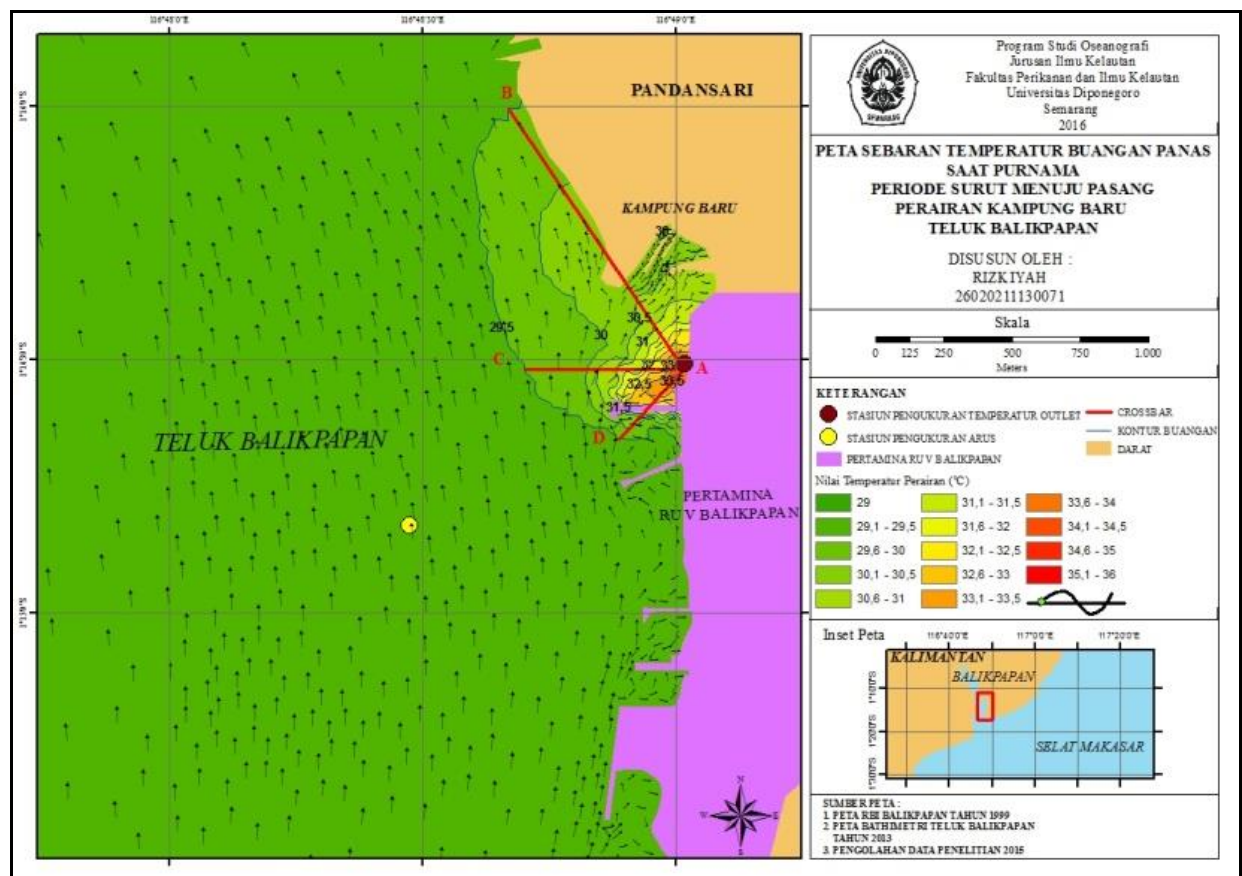

Gambar 14. Pola sebaran temperatur buangan panas pada saat purnama periode surut menuju pasang di Perairan Kampung Baru, Teluk Balikpapan

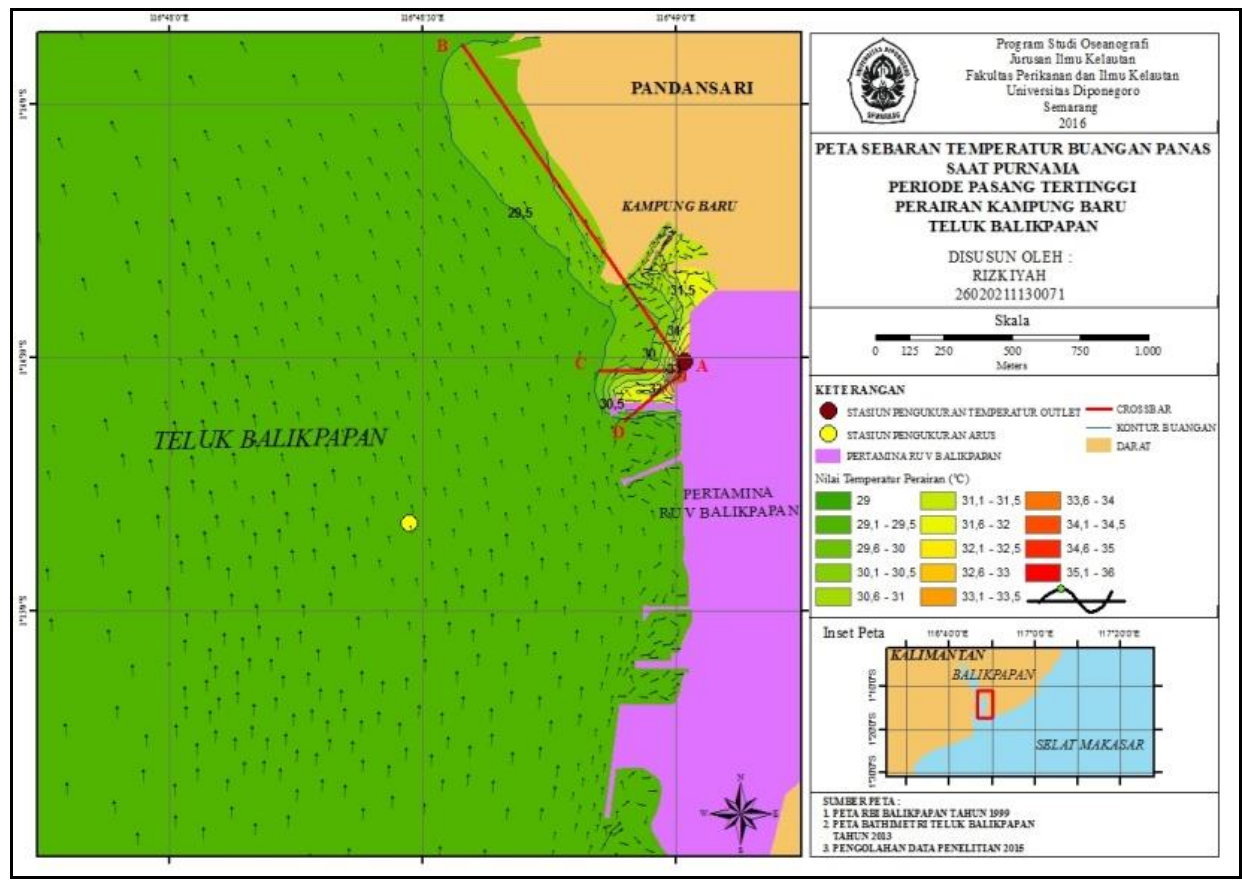

Gambar 15. Pola sebaran temperatur buangan panas pada saat purnama periode pasang tertinggi di Perairan Kampung Baru, Teluk Balikpapan 


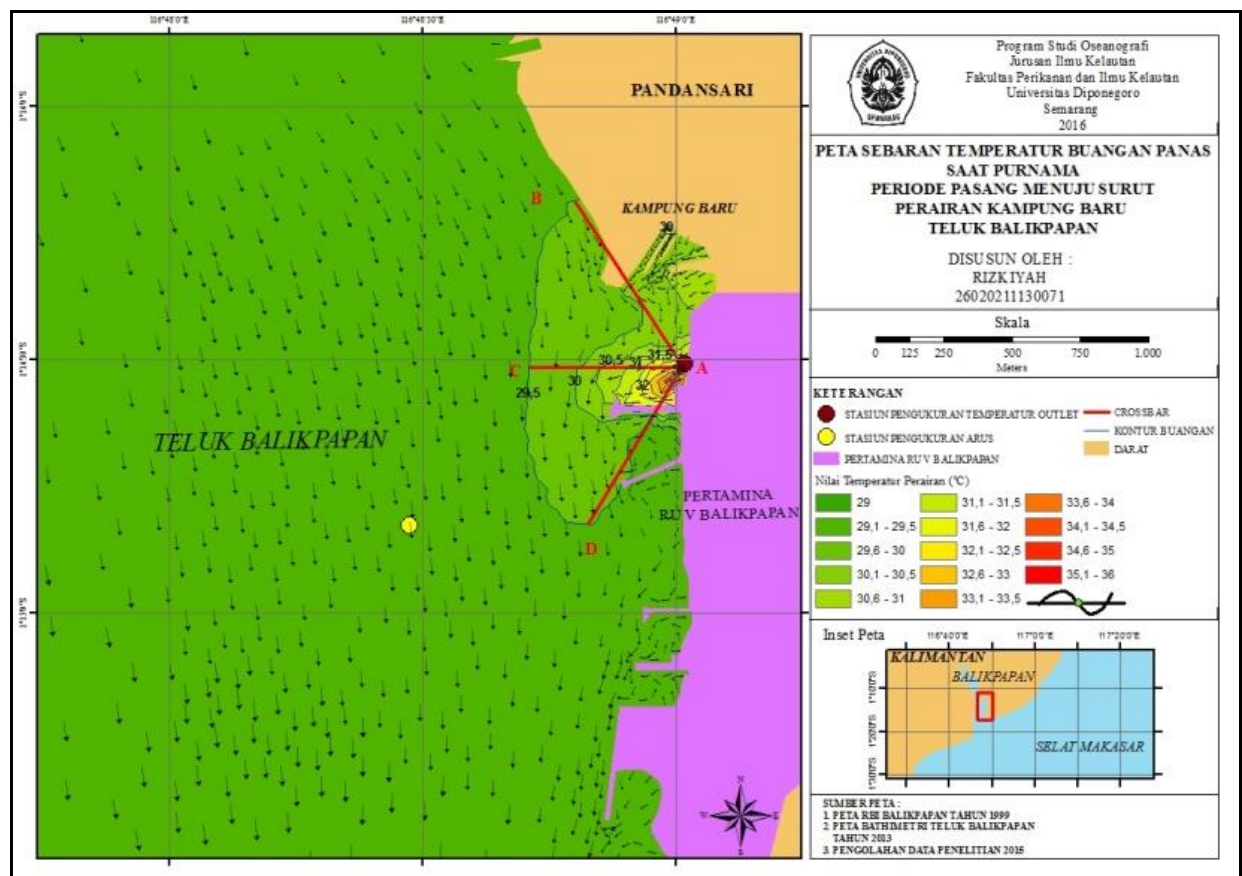

Gambar 16. Pola sebaran temperatur buangan panas pada saat purnama periode pasang menuju surut di Perairan Kampung Baru, Teluk Balikpapan

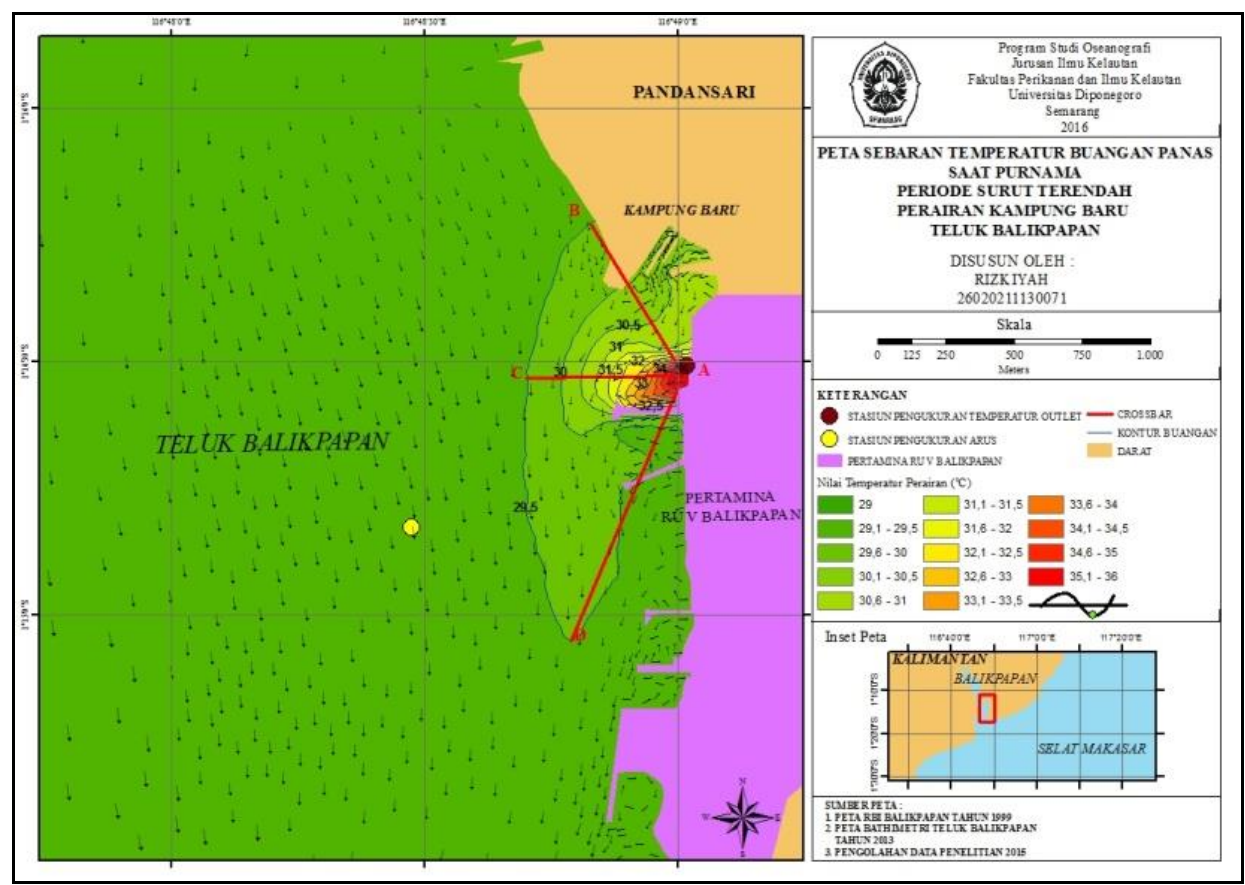

Gambar 17. Pola sebaran temperatur buangan panas pada saat purnama periode surut terendah di Perairan Kampung Baru, Teluk Balikpapan 


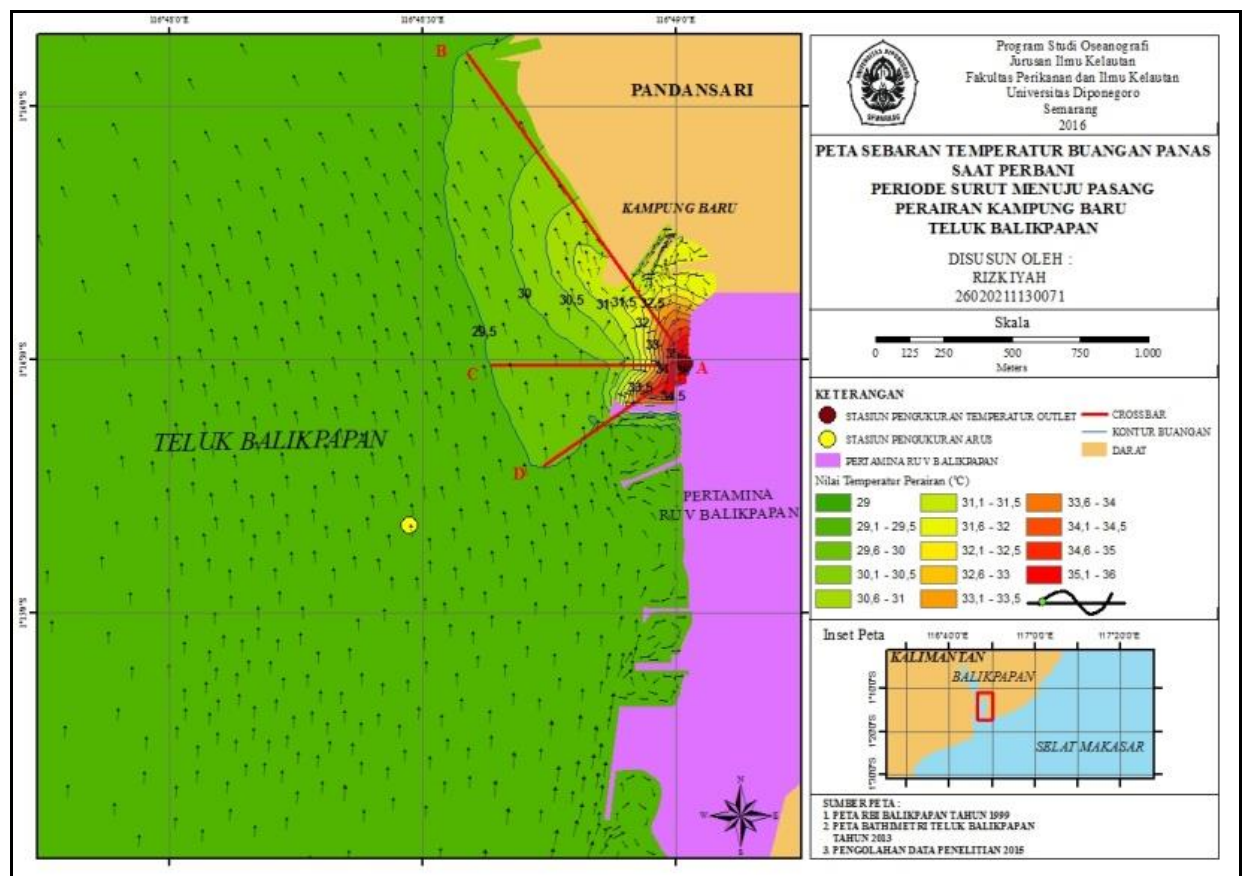

Gambar 18. Pola sebaran temperatur buangan panas pada saat perbani periode surut menuju pasang di Perairan Kampung Baru, Teluk Balikpapan

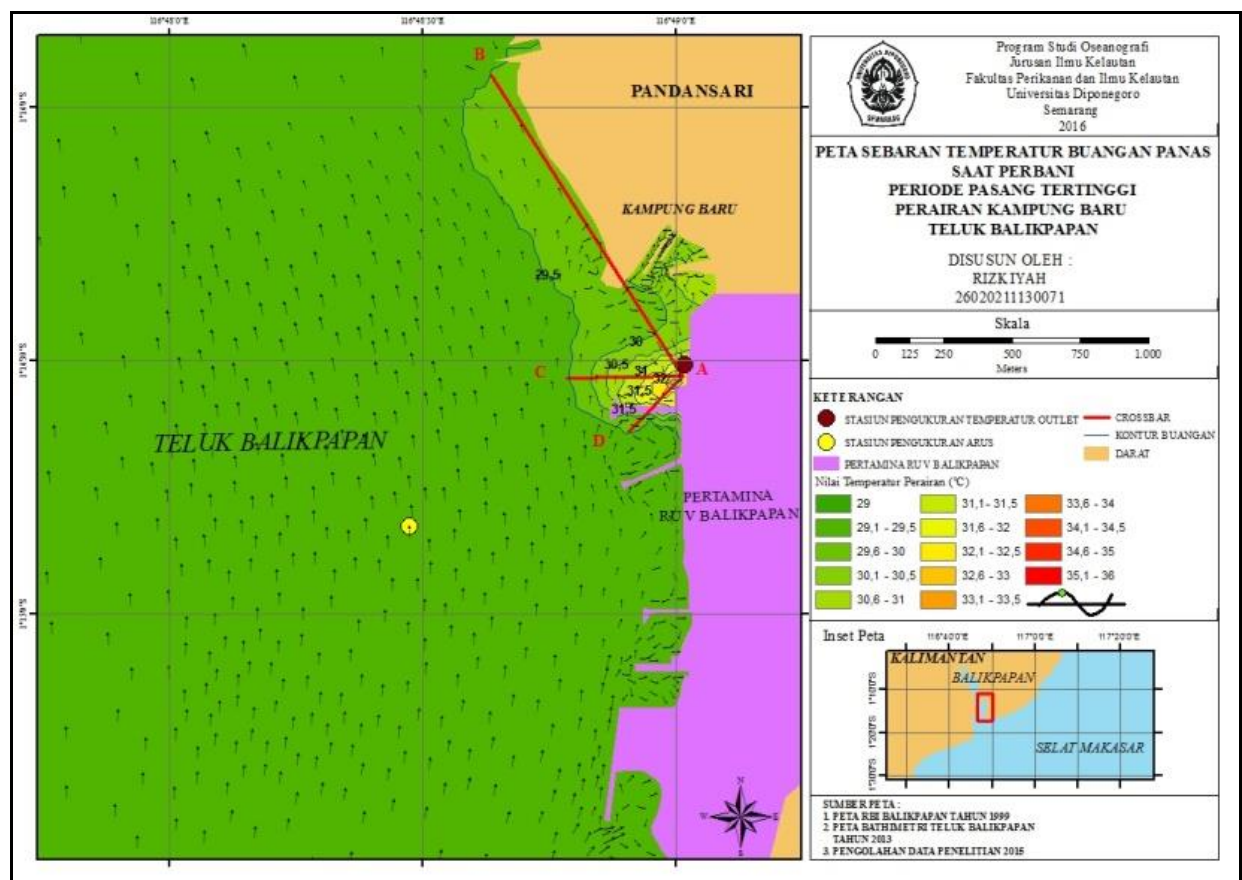

Gambar 19. Pola sebaran temperatur buangan panas pada saat perbani periode pasang tertinggi di Perairan Kampung Baru, Teluk Balikpapan 


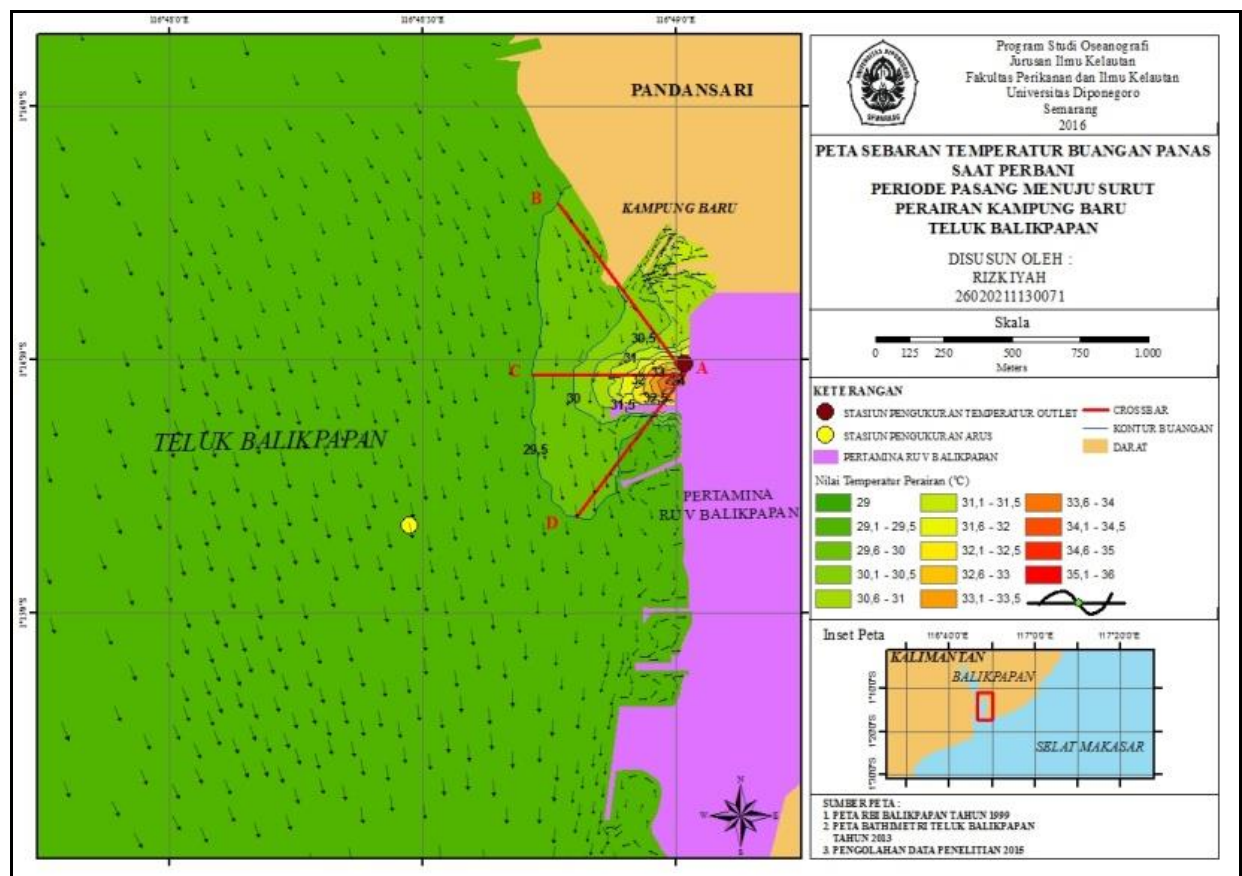

Gambar 20. Pola sebaran temperatur buangan panas pada saat perbani periode pasang menuju surut di Perairan Kampung Baru, Teluk Balikpapan

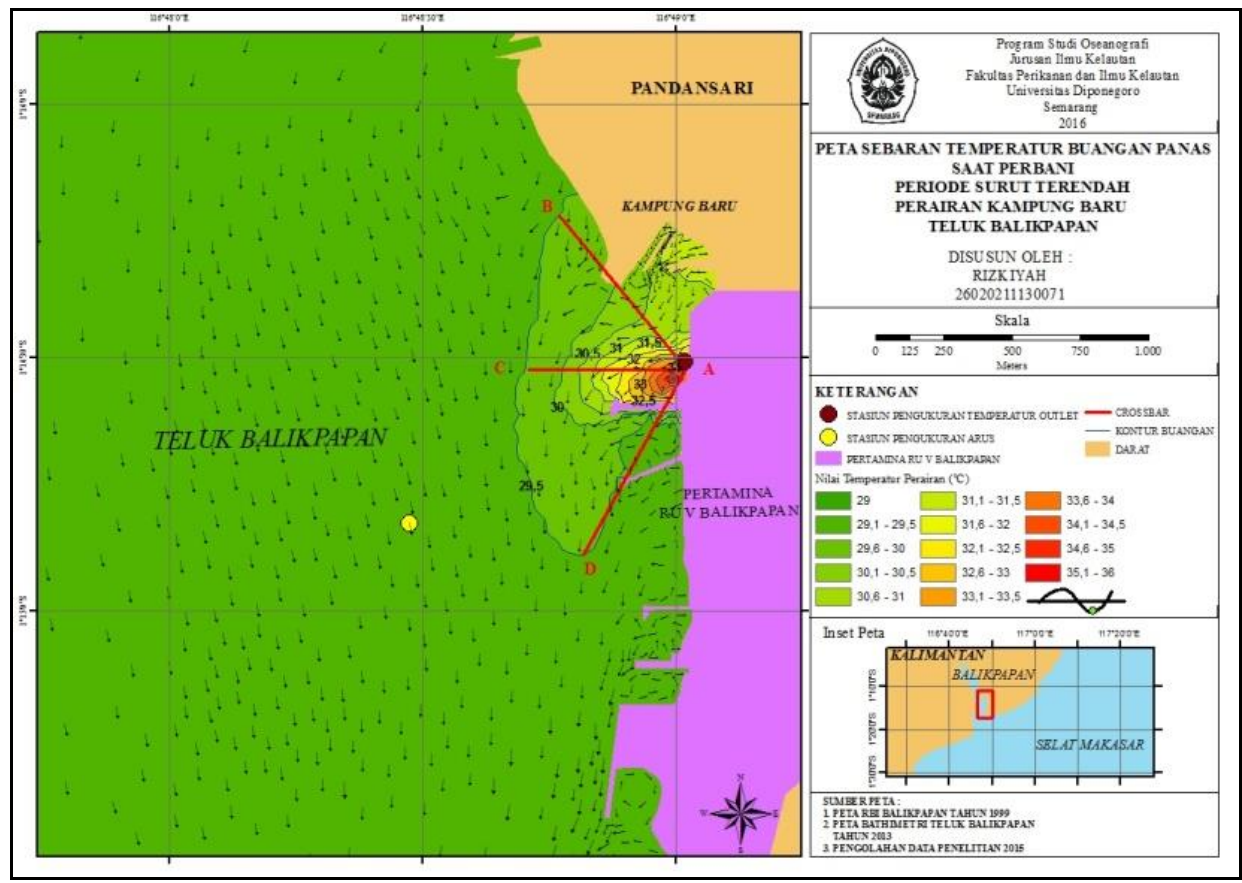

Gambar 21. Pola sebaran temperatur buangan panas pada saat perbani periode surut terendah di Perairan Kampung Baru, Teluk Balikpapan 


\section{SIMPULAN}

Berdasarkan hasil penelitian ini dapat disimpulkan bahwa, pola sebaran buangan air bertemperatur tinggi di Perairan Kampung Baru Teluk Balikpapan mengikuti pola pergerakan arusnya yang memiliki kecepatan berkisar 0,01 $\mathrm{m} / \mathrm{det}-0,53 \mathrm{~m} / \mathrm{det}$, serta dipengaruhi adanya bangunan pantai yang ada di sekitarnya. Jarak terjauh sebaran panas terjadi saat kondisi purnama periode pasang tertinggi yaitu sebesar $1,44 \mathrm{~km}$ kearah selatan dengan suhu $29,5^{\circ} \mathrm{C}$ selama kurun waktu pemodelan berlangsung.

\section{DAFTAR PUSTAKA}

Cahyana, C. 2011. Model Sebaran Panas Air Kanal Pendingin Instalasi Pembangkit Listrik ke Badan Air Laut. [Tesis]. Fakultas Matematika dan Ilmu Pengetahuan Alam, Program Studi Ilmu Kelautan, Universitas Indonesia.

Poerbandono dan Poerbandono dan E. Djunasjah. 2005. Survei Hidrografi. Refika Aditama, Bandung.

Hadi, S. dan Radjawane, I. 2009. Arus Laut. Institut Teknologi Bandung Press, Bandung.

Triatmodjo, B. 1999. Teknik Pantai. Beta Offset, Yogyakarta.

Sugiyono. 2008. Metode Penelitian Kuantitatif Kualitatif dan R\&D. Alfabeta, Bandung.

Tahir, A dan Susilo. 2002. Analisis Kesesuaian Lahan dan Kebijaksanaan Pemanfaatan Ruang Kawasan Pesisir Teluk Balikpapan. Jurnal Pesisir dan Laut IPB., 4(3):1-16. 